\title{
Guillain-Barré syndrome associated with pulmonary tuberculosis
}

\author{
Aza A M Taha, Kim Huat Augustine Tee \\ Department of Respiratory and Critical Care Medicine, Changi General Hospital, Singapore, Singapore
}

Correspondence to Dr Aza A M Taha, azataha75@gmail.com

\section{Summary}

A 47-year-old male smoker admitted complaining of progressive bilateral lower-limb and upper-limb weakness, without any numbness. He also complained of productive cough and fever for the last 2 weeks before admission. There were no nasal symptoms, sore throat, night sweats, loss of appetite and weight, nor did he have any gastrointestinal symptoms.

\section{BACKGROUND}

Association of TB with Guillain-Barré syndrome (GBS) is far from being clear; furthermore, diagnosis of $\mathrm{TB}$ in a patient with GBS might be challenging due to respiratory muscle weakness and difficulty to expectorate sputum.

\section{CASE PRESENTATION}

A 47-year-old male smoker complaining of progressive bilateral lower limbs and upper limbs weakness, without any numbness, was admitted to our hospital. He also complained of productive cough and fever for the last 2 weeks before admission. There were no nasal symptoms, sore throat, night sweats, loss of appetite and weight, nor did he have any gastrointestinal symptoms.

On admission, he was febrile with a respiratory rate of 18 breaths/min with decreased left sided chest expansion and left basal crackles. Neurological examination revealed a grade 3 of 5 symmetrical lower-limb weakness and grade 4 of 5 symmetrical upper-limb weakness. Importantly, he had absent tendon reflexes in lower limbs and depressed tendon reflexes in both upper limbs. Sensation and anal sphincteric tone were both normal. Our patient did not have any facial weakness or eye movement disorder.

\section{INVESTIGATIONS}

Results of laboratory investigations showed haemoglobin $16.3 \mathrm{~g} / \mathrm{dl}$, normal white cell count $5900 \mathrm{cells} / \mu \mathrm{l}$, platelet count $550000 \mathrm{cell} / \mu \mathrm{l}$, serum protein $63 \mathrm{~g} / \mathrm{l}$, serum albumin $23 \mathrm{~g} / \mathrm{l}$, aspartate aminotransferase $71 \mathrm{IU} / 1$, alanine aminotransferase $50 \mathrm{IU} / \mathrm{l}$, alkaline phosphatase $72 \mathrm{IU} / \mathrm{l}$, urea $3.3 \mathrm{mmol} / \mathrm{l}$, creatinine $64 \mu \mathrm{mol} / \mathrm{l}$, serum potassium $4.3 \mathrm{mmol} / \mathrm{l}$, serum glucose $8.4 \mathrm{mmol} / \mathrm{l}$, serum $\mathrm{C}$ reactive protein $43.8 \mathrm{mg} / \mathrm{l}$ and procalcitonin of $0.53 \mu \mathrm{g} / \mathrm{l}$. Cerebrospinal fluid revealed cell count of 3 , glucose $4.5 \mathrm{mmol} / \mathrm{l}$, protein $0.18 \mathrm{~g} / \mathrm{dl}$. with a negative yield on bacterial and mycobacterial smears and cultures. HIV test was negative.

A non-contrast CT scan of the brain did not show any acute haemorrhage or infarct; chest radiograph revealed a confluent cavitating opacity in the left lower zone. The chest CT scan confirmed a large consolidation with air bronchogram in the lingula, left upper and lower lobes with minimal pleural effusion and no pleural enhancement (figures 1-3).

Blood and urine cultures were negative, and serum Melioidosis serology was negative. The patient had a weak cough and was unable to expectorate representative sputum, despite induction with nebulised saline.

His slow vital capacity was moderately reduced at 2.51 1. with normal maximum inspiratory pressure at $75 \mathrm{~cm}$ $\mathrm{H}_{2} \mathrm{O}$. As expected, he showed a moderately reduced maximum expiratory pressure at $63 \mathrm{~cm} \mathrm{H}_{2} \mathrm{O}$.

The patient was started on a 5-day course of intravenous immunoglobulin on clinical suspicion of Gullian-Barré syndrome, with concomitant empirical broad-spectrum antibiotics for community acquired pneumonia.

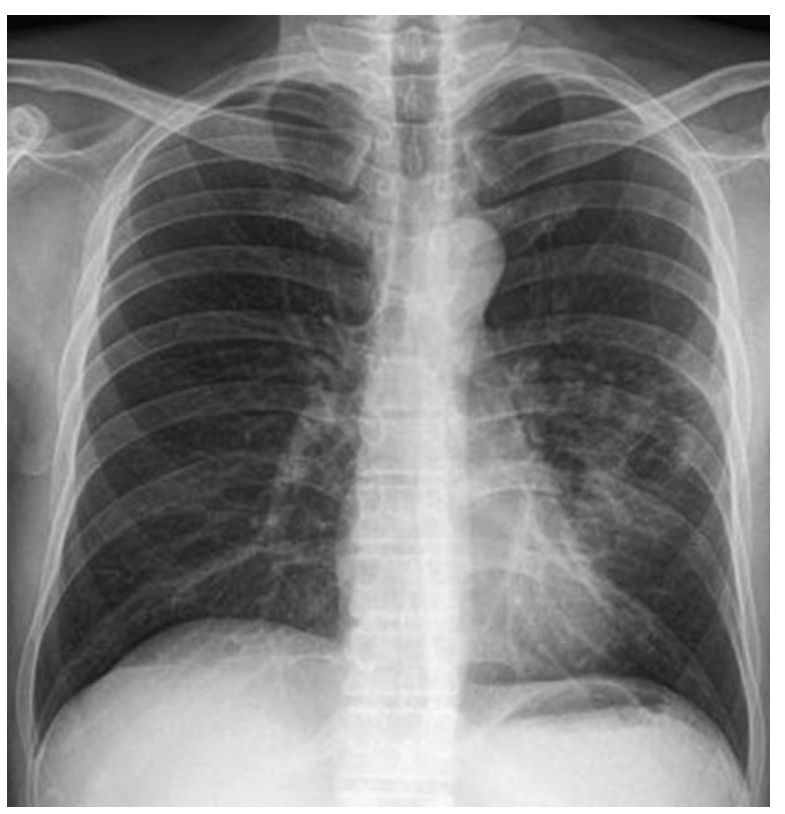

Figure 1 Chest x-ray of the chest at presentation of patient showing consolidation and cavitation. 


\section{BMJ Case Reports}

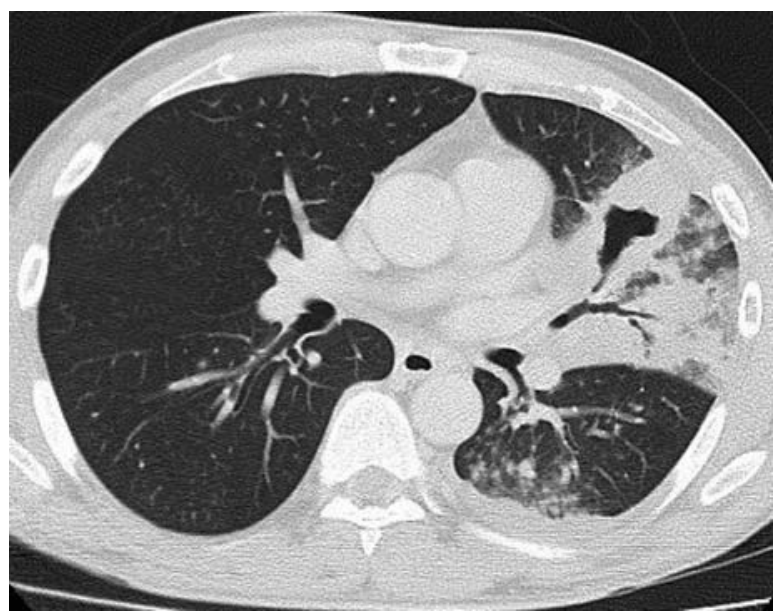

Figure 2 CT scan of the chest at presentation of patient showing consolidation and cavitation.

Nerve conduction studies at day 7 of illness showed mild conduction slowing down at the fibula neck (both peroneal nerves), elbow (right ulnar nerve) and leg segment (right tibial); F-wave latencies were slightly prolonged in both lower limbs. Overall findings reaffirmed the diagnosis of GBS.

\section{TREATMENT}

The patient was started on a 5-day course of intravenous immunoglobulin on clinical suspicion of Gullian-Barré syndrome, with concomitant empirical broad-spectrum antibiotics for community acquired pneumonia.

Seventy-two hours after initiating antibiotics, he continued to be febrile with unremitting cough. He underwent bronchoscopy and bronchoalveolar lavage from the lingula lobe segments which revealed acid-fast bacilli $4+$. Isoniazid, rifampicin, ethambutol and pyrazinamide were

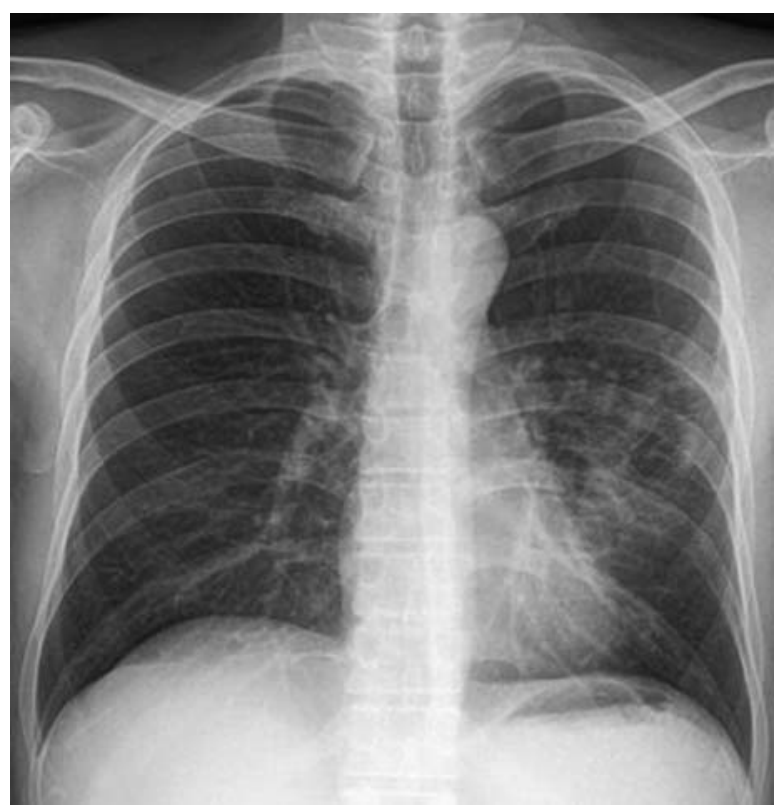

Figure 3 Chest $x$-ray of the patient 6 months after initial presentation showing minimal fibrotic sequelae. started for pulmonary tuberculosis disease. His fever promptly defervesce and respiratory symptoms subsided. Upon discharge after 3 weeks, he was able to ambulate with a walking frame. Further reviews in the subsequent 2 months showed clinical resolution and radiological clearance of the consolidation and significant improvement of his lower-limb weakness.

\section{OUTCOME AND FOLLOW-UP}

Upon discharge after 3 weeks, he was able to ambulate with a walking frame. Further reviews in the subsequent 2 months showed clinical resolution and radiological clearance of the consolidation and significant improvement of his lower-limb weakness.

\section{DISCUSSION}

GBS is viewed as a reactive, self-limited, autoimmune disease triggered by a preceding bacterial or viral infection. Approximately two-thirds of patients give a history of an antecedent respiratory tract or gastrointestinal infection. A case control study from the UK has found that $26 \%$ of patients affected by GBS had evidence of Campylobacter jejuni infection. ${ }^{2}$ Patients with Campylobacter-associated GBS appear to have slower recovery and greater neurological disability. ${ }^{2}$ Our patient did not have any gastrointestinal symptom therefore serological tests for the detection of $C$ jejuni was not ordered.

Treatment of GBS consists mainly of supportive measures and as well as disease-modifying treatment. According to a 2003 practice parameter from the American Academy of Neurology on immunotherapy for GBS, Intravenous immune globulin (IVIG) is as effective as plasma exchange for the treatment of GBS. ${ }^{3}$ Steroid has no role in the treatment of GBS as it has not been shown to be beneficial. ${ }^{4}$

The patient's chest $\mathrm{x}$-ray showed cavitation which is a recognised finding in pulmonary $\mathrm{TB}$ and Burkholderia pseudomallei (melioidosis). Melioidosis occurs predominantly in Southeast Asia northern Australia, South Asia (including India) and China. ${ }^{5}$ Pneumonia is the most common clinical presentation of melioidosis. ${ }^{5}$ Therefore, in the endemic areas it is important to obtain microbiological diagnosis of TB before starting anti-tuberculous medication as treatment regimen and duration of therapy is different from that of melioidosis.

To our knowledge, association of pulmonary tuberculosis and GBS has been reported only in a published report of two case studies. ${ }^{6}$

In our case, GBS could be coincidental finding but it could also be an autoimmune reaction to tuberculous bacilli and it can be due to direct nerve root invasion by TB bacilli.

Early microbiological detection of the active pulmonary tuberculosis in the case of respiratory muscle weakness can be clinically challenging, even as a cavitatory lung lesion might possibly be harbouring a higher acid-fast bacilli burden.

Our case also demonstrated the importance of thorough investigation for infection in a patient with GBS since early treatment of specific infections may change the morbidity and mortality of the patient. With suspicion of pulmonary infection, early bronchoscopic sampling might be worth considering. 


\section{BMJ Case Reports}

\section{Learning points}

- In Guillain-Barré syndrome (GBS) infection needs to be excluded.

- Early microbiological detection of TB might be difficult in cases of GBS with respiratory muscle weakness.

- If clinically indicated bronchoscopy should be considered in patients of GBS for microbiological diagnosis.

Competing interests None.

Patient consent Obtained.

\section{REFERENCES}

1. Hahn AF. Guillain-Barré syndrome. Lancet 1998;352:635.

2. Rees JH, Soudain SE, Gregson NA, et al. Campylobacter jejuni infection and Guillain-Barré syndrome. N Engl J Med 1995;333:1374.

3. Hughes RA, Wijdicks EF, Barohn R, et al. Practice parameter: immunotherapy for Guillain-Barré syndrome: report of the Quality Standards Subcommittee of the American Academy of Neurology. Neurology 2003;61:736.

4. Hughes RA, Swan AV, van Koningsveld R, et al. Corticosteroids for Guillain-Barré syndrome. Cochrane Database Syst Rev 2006;CD001446.

5. Cheng AC, Currie BJ. Melioidosis: epidemiology, pathophysiology, and management. Clin Microbiol Rev 2005;18:383.

6. Vyravanathan S, Nimal S. Guillain-Barré syndrome associated with tuberculosis. Postgraduate Med J 1983;59:516-17.

7. Wong KS. Validity of symptoms and radiographic features in predicting positive AFB smears in adolescents with tuberculosis. Int J Tuberc Lung Dis 2010;14:155-9.

This pdf has been created automatically from the final edited text and images.

Copyright 2012 BMJ Publishing Group. All rights reserved. For permission to reuse any of this content visit http://group.bmj.com/group/rights-licensing/permissions.

BMJ Case Report Fellows may re-use this article for personal use and teaching without any further permission.

Please cite this article as follows (you will need to access the article online to obtain the date of publication).

Taha AAM, Tee KHA. Guillain-Barré syndrome associated with pulmonary tuberculosis. BMJ Case Reports 2012;10.1136/bcr-01-2012-5484, Published XXX

Become a Fellow of BMJ Case Reports today and you can:

- Submit as many cases as you like

- Enjoy fast sympathetic peer review and rapid publication of accepted articles

- Access all the published articles

- Re-use any of the published material for personal use and teaching without further permission

For information on Institutional Fellowships contact consortiasales@bmjgroup.com

Visit casereports.bmj.com for more articles like this and to become a Fellow 